\title{
PERANCANGAN INTERIOR AULA, RUANG TRANSIT, PERPUSTAKAAN DAN KANTOR MASJID AGUNG AL AQSHA KLATEN
}

\author{
Lalang Madyo Prakoso ${ }^{1}$, Indarto ${ }^{2}$ \\ Program Studi S-1 Desain Interior, Fakultas Seni Rupa dan Desain \\ Institut Seni Indonesia (ISI) Surakarta \\ 1Email: lalankqiquk300@gmail.com \\ 2Email: hanindart@gmail.com
}

\begin{abstract}
Al Aqsa Great Mosque is a tourist attraction because of its location on the edge of the SoloYogyakarta Highway, it is necessary to design an interior that reflects the distinctive characteristics of the Regency of Klaten that carries the theme of Batik Bayat is one of the superior products of the Regency of Klaten. Carrying the postmodern style, mixing two styles namely modern with traditional. Batik Bayat has the characteristic of using one color and tends to be dark brown or black. Bayat Batik has a distinctive motif that does not exist in other batik industry areas. Batik motifs typical of Bayat include white background, take a piece of coffee or broken coffee, and crumble.
\end{abstract}

Keywords: Mosque, Klaten, Postmodern, Bayat Batik.

\section{PENDAHULUAN}

Berbicara tentang Kabupaten Klaten terdapat salah satu tempat yang dijadikan ikon Kabupaten Klaten yaitu Masjid Agung Al Aqsha karena memiliki desain yang sangat megah dan mewah. Terlebih lagi Masjid Agung Al Aqsha terletak di lokasi yang strategis, tepat di pinggir jalan Solo-Yogyakarta sehingga dapat terlihat keelokan desain arsitekturnya ketika melintasi jalan tersebut. Tak jarang masjid ini dijadikan tempat transit bagi para pengemudi untuk sholat atau bahkan sekedar berkunjung untuk menikmati keindahan masjid tersebut.

Masjid agung Al Aqsha yang dijadikan ikon di Kabupaten Klaten, maka perlu perancangan interior yang mencerminkan ciri khas kebudayaan lokal Kabupaten Klaten yaitu dengan mengusung tema Batik Bayat yang merupakan salah satu produk unggulan khas Kabupaten Klaten, agar orang tahu bahwa Masjid Agung Al Aqsha adalah masjid agung yang ada di Kabupaten Klaten. Masjid yang dibangun di lahan seluas 5.200 meter persegi dengan kapasitas jamaah mencapai 3.000 jamaah, parkiran yang mampu menampung ratusan sepeda motor dan puluhan mobil, serta bagian luar masjid dihiasi dengan taman dan kolam.

Masjid Agung Klaten memiliki 3 lantai dan dibagi menjadi beberapa ruangan yaitu ruangan utama yang digunakan untuk para jamaah berada dilantai 2 dan 3 dan terdapat tangga pada pintu utama untuk memisahkan antara jamaah putra dan jamaah putri. Mihrab memiliki tinggi 10 meter berwarna emas dan dihiasi ukiran surat Al Fatihah dan Al Isra'. Dilengkapi dengan berbagai fasilitas seperti ruang transit, kamar mandi bersih, perpustakaan serta kantor untuk pengelolaan masjid tersebut.

Masjid Agung Klaten yang memiliki gaya postmodern. Gaya interior postmodern bermula dari kejenuhan masyarakat terhadap gaya interior modern, maka timbullah gerakan 
pembenahan dari para arsitek. Arsitektur post modern ini muncul dalam tiga versi atau sub langgam yaitu purna modern, pasca modern, dan dekonstruksi. Charles Jencks mengemukakan bahwa gaya postmodern merupakan paduan dari dua gaya atau style, yaitu gaya interior modern dengan gaya lainnya (double coding of style). Sesuai dengan letaknya di Kabupaten Klaten Provinsi Jawa Tengah, maka gaya interior postmodern kali ini akan mengkombinasikan gaya modern timur Tengah dengan sentuhan interior tradisional mengambil tema Batik Bayat yang merupakan ciri khas Kabupaten Klaten.

Ruang lingkup garap pada perancangan interior Masjid Agung Al Aqsha di Klaten yaitu

1. Ruang Aula adalah ruang yang digunakan untuk seminar dan rapat, ruangan bersifat publik yang menunjukkan tema Batik Bayat yang diaplikasikan pada bagian dinding yaitu GRC cetak dengan motif Batik Bayat dan juga karpet warna merah dengan bagian ujung motif batik.

2. Ruang Transit VIP adalah ruangan yang dibuat sebagai ruang transit bagi pengisi ceramah atau seminar dan juga sebagai ruang transit bagi tamu penting misalnya ulama besar. Terdapat ruang tunggu, kicthen set, kamar mandi dan juga kamr tidur. Bagian dinding menggunakan GRC cetak dengan motif Batik Bayat dipadukan dengan bahan marmer pada lantai.

3. Ruang Perpurtakaan merupakan ruangan yang dibuat khusus untuk menyimpan dokumen sejarah dan juga alat-alat digital serta buku-buku tentang keagamaan yang dapat dikunjungi oleh para jamaah Masjid Agung Al Aqsha. Ruangan dibuat dengan tema Batik Bayat yang diaplikasikan pada list tembok dipadukan dengan marmer untuk lantainya.

4. Ruang Kantor Pengurus dibuat untuk pengurus-pengurus masjid mengerjakaan pekerjaannya sesuai tugas masing-masing. Ruangan dibuat dengan tema batik bayat yang diaplikasikan pada dinding dengan menempelkan GRC cetak yang bermotif Batik Bayat.

Perancangan interior aula, ruang transit, perpustakaan dan kantor untuk menunjang Masjid Agung Al Aqsha di Klaten dengan gaya postmodern ditujukan kepada pengunjung dan masyarakat sekitar. Untuk mewujudkan dan menunjang perancangan tersebut, diperlukan beberapa pendekatan untuk memecahkan desain, dan pendekatan yang dipilih adalah pendekatan fungsi, pendekatan ergonomi, pendekatan estetis dan pendekatan tema.

\section{Pendekatan Fungsi}

Desain yang baik adalah desain yang tidak hanya memenuhi kebutuhan visual, tetapi juga kebutuhan fungsional. Seiring dengan perkembangan peradaban manusia, fungsi interior memiliki sejuta makna yang harus ditangkap yang selanjutnya dapat diterjemahkan oleh seorang desainer (Sunarmi, 2008:46).

\section{Pendekatan Ergonomi}

Ergonomi merupakan salah satu dari persyaratan untuk mencapai desain yang qualified, certified, dan customer need, sehingga menjadi keterkaitan yang simultan dan menciptakan sinergi dalam memunculkan gagasan desain, sehingga desain yang dirancang merasa aman, nyaman dan efektif (Laksmi, 2006:61-73). Pendekatan Ergonomi ini diterapkan pada perancangan interior aula, ruang transit, perpustakaan dan kantor untuk menunjang Masjid Agung Al Aqsha di Klaten untuk mengetahui ilmu-ilmu biologi manusia pada dasar perancangan yaitu anatomi, antrophometri, fisiologi, dan psikologi, agar pengunjung dan pengelola Masjid Agung Al-Aqsha di Kabupaten Klaten merasa aman dan nyaman dalam melakukan segala 
aktivitas.

Lingkup ergonomis/antropometris yang dibahas adalah tentang kenyamanan, keamanan, dan kesehatan. Aplikasi konsep ergonomis berbeda-berbeda untuk setiap penggunanya. Hal ini berdasarkan ukuran fisik pengguna dan fasilitas yang digunakan. Ukuran fisik pengguna ditentukan oleh usia, ras dan karakter khusus masing-masing, sehingga fasilitasnya pun akan disesuaikan dengan ukuran pengguna.

3. Pendekatan Estetika

Ilmu Estetika adalah suatu ilmu yang mempelajari segala sesuatu yang berkaitan dengan keindahan, mempelajari semua aspek dari apa yang kita sebut keindahan (Djelantik, 1999:9). Keindahan menjadi salah satu unsur yang diperhatikan dalam perancangan desain interior. Sejalan dengan hal tersebut, prinsip desain memiliki makna hakikat penyusunan, pengorganisasian, ataupun komposisi dari unsur-unsur budaya. Selain itu, komposisi estetik juga diperlukan dalam perancangan desain interior yang meliputi: harmony, contrast, repetition, unity, balance, simplicity, accentuation, dan proportion.

Proses perancangan desain interior jika dikaitkan dengan pendekatan estetis perlu memperhatikan beberapa kriteria. Kriteria tersebut meliputi (Ching, 2011:42) :

a. Skala yang sesuai dengan fungsi ruang.

b. Pengelompokan visual, kesatuan dengan variasi.

c. Pemahaman figure ground.

d. Komposisi tiga dimensi, ritme, harmoni, keseimbangan.

e. Orientasi cahaya, pemandangan, dan internal fokus yang memadai.

f. Bentuk warna tekstur dan pola

Berdasarkan kriteria di atas, maka pendekatan estetis menjadi ide perancangan atau gagasan pokok. Pendekatan estetis akan menjadi inspirasi untuk melakukan desain elemen pada interior, sehingga mampu menjawab permasalahan desain dari sisi keindahan.

4. Pendekatan Tema/Gaya

Pendekatan pemecahan desain kaitannya pendekatan tema perancang dapat menggunakan pendekatan kaitannya dengan identitas sebuah wadah untuk penciptaan suasana. Penciptaan suasana interior penting diwujudkan, dengan harapan orang akan menangkap pesan rasa dari interior yang dirancang, akhirnya orang akan selalu ingat dan ingin kembali hadir menikmati suasana tersebut, kondisi demikian sangat diperlukan untuk bangunan umum, baik bangunan umum sebagai wadah menjual jasa maupun kebutuhan sehari-hari manusia. Suasana interior dapat dihadirkan melalui gaya interior ataupun system pelayanan, melalui gaya interior dapat menghadirkan bagian dari gaya Interior dalam unsur pembentuk ruang ataupun isian ruang.

Tema perancangan interior aula, ruang transit, perpustakaan dan kantor untuk menunjang Masjid Agung Al Aqsha di Klaten adalah ciri khas dan muatan budaya lokal dari Kabupaten Klaten yaitu batik bayat dikemas dengan gaya/konsep postmodern yang akan ditransformasikan ke dalam berbagai bentuk furniture dan wallpaper. Postmodern merupakan paduan dari dua gaya atau style, yaitu gaya interior modern dengan gaya lainnya (double coding of style). Kali ini desainer akan memadukan interior modern dengan sentuhan Jawa Tengah, sesuai dengan letak Masjid Agung Al-Aqsha di Kabupaten Klaten.

5. Ide Perancangan

Merancang ruang interior terkait Masjid Agung Al Aqsha, secara umum dirancang dengan memasukkan pendekatan yang dibahas. Tema perancangan interior aula, 
ruang transit, perpustakaan dan kantor untuk menunjang Masjid Agung Al Aqsha di Klaten adalah salah satu khas budaya lokal dari Kabupaten Klaten yaitu batik brayat yang dikemas dengan gaya/konsep post modern. Postmodern merupakan paduan dari dua gaya atau style, yaitu gaya interior modern dengan gaya lainnya (double coding of style). Kali ini desainer akan memadukan interior modern dengan sentuhan Jawa Tengah, sesuai dengan letak Masjid Agung Al Aqsha di Kabupaten Klaten.

Sejarah kerajinan membatik di daerah Bayat diperkirakan sudah ada sejak masa pra Hindu dan mulai berkembang sejak datangnya $\mathrm{Ki}$ Ageng Pandanaran. Sejak abad ke 17. Tembayat atau yang sekarang lebih dikenal dengan Bayat merupakan daerah penghasil batik. Alkisah, Ki AgengPandanaranberangkatkeBayatmengikuti perintah Sunan Kalijaga untuk melakukan tapa dan menjalankan kehidupan religius. Begitu sohornya contoh hidup Pandanaran hingga ia pun lebih sering dikenal sebagai Sunan Bayat. Konon, sembari menyebarkan Islam, ia juga mengajari rakyat di Bayat, khususnya di Desa Paseban, keterampilan membatik. Tujuannya adalah untuk pemenuhan kebutuhan pakaian Sunan beserta sanak familinya.

Masyarakat Bayat tergolong dinamis dan terbuka, namun tetap berpegang pada tatanan kehidupan sebagai orang Jawa. Sikap hidup ini menjadi filosofi batik Tembayat dalam membuat setiap helai batiknya. Batik Bayat memiliki ciri khas gaya dan bentuknya yaitu menggunakan satu warna dan cenderung coklat tua dan hitam menjadi karakter atau gaya batik Bayat. Batik bayat juga menggunakan warna natural, yang merupakan pewarnaan kain batik dengan menggunakan bahan-bahan alami, seperti dari kulit pohon mahoni, kulit pohon duwet, kulit pohon secang, dan kulit pohon tangi. Batik Bayat juga mempunyai motif khas, yang tidak ada pada daerah industri batik lainnya. Motif batik khas Bayat antara lain latar putih, kambil secukil atau kopi pecah, dan remukan.

\section{Elemen Pembentuk Ruang}

a. Lantai

Lantai merupakan bidang datar dan dijadikan sebagai alas dari ruang dimana aktivitas manusia dilakukan di atasnya dan mempunyai sifat atau peranan sendirisendiri yaitu akan mempertegas fungsi ruang (Suptandar, 1999:127). Elemen pembentuk ruang mempunyai fungsi yang sangat besar dalam kelancaran aktivitas manusia dalam ruang.

Manusia melakukan aktivitas dengan berjalan atau menginjak lantai. Banyak faktorfaktor yang harus diperhatikan pada lantai. Adapun persyaratan untuk lantai yaitu :

1) Lantai harus kuat dan mampu menahan beban di atasnya.

2) Mudah dibersihkan.

3) Kedap suara.

4) Tahan terhadap kelembaban.

5) Memberikan rasa hangat pada kaki dan sebagainya.

Karakteristik lantai akan memberikan ciri tertentu terhadap ruang yang bersangkutan dengan jenis kegiatan yang ada dalam bidang tersebut.

1) Area parkir, lantai dilapisi aspal sebagai petunjuk arah pada kendaraan-kendaraan atau mempergunakan tanda-tanda. Bangunan dengan tingkat kebisingan tinggi, maka sebaiknya digunakan lantai yang tidak tereonansi sehingga suara dalam ruang tidak terlalu bising. Untuk memperluas serta menyatukan ruangruang dapat digunakan bahan penutup lantai yang sama.

2) Ruang-ruang tertentu seperti kamar mandi, WC dipilih jenis lantai yang kedap air serta warna pola yang serasi dengan fungsi dan juga perawatannya.

3) Ruang publik seperti lobby, ruang desain 
serta bangunan umum lainnya, lantai dipasang pada jalur lintas orang berjalan dengan motif yang berbeda-beda agar memberikan kesan adanya perbedaan antara ruang-ruang yang ada di dalam bangunan tersebut.

4) Koridor-koridor dimana pengunjung akan menuju ke ruang-ruang lain diusahakan untuk mengurangi pandangan-pandangan yang monoton dengan melewati lantai dari material yang berlainan baik tekstur, warna maupun motif-motifnya.

Sesuai dengan tema dan gaya yang telah ditentukan, lantai pada desain interior Masjid Agung Al Aqsha di Klaten ini akan menggunakan lantai marmer yang berukuran $60 \times 60$, tetapi pada aula menggunakan karpet warna merah.

\section{b. Dinding}

Dinding dalam suatu bangunan merupakan faktor yang banyak kegunaannya, untuk itu penyelesaiannya harus disesuaikan dengan fungsi ruang atau bangunan tersebut. Dinding merupakan unsur terpenting terbentuknya suatu ruang, seperti yang dikatakan oleh Pamudji Suptandar dalam proses perancangan suatu ruang interior, dinding mempunyai peranan yang cukup besar dan memerlukan perhatian khusus, disamping terdapat unsur-unsur lainnya seperti tata letak, desain furniture serta peralatan-peralatan lain yang akan disusun bersama dalam suatu kesatuan dengan dinding (Suptandar, 19999:147). Secara keseluruhan, dinding adalah suatu bidang nyata yang membatasi suatu ruang yang mempunyai jenis berbeda, sehingga dalam perancangan suatu ruang interior dinding mempunyai perhatian yang besar untuk memperoleh suasana sejuk, nyaman dan gembira. Adapun elemen dinding terdiri dari jendela dan pintu.

Adapun fungsi dinding dalam bangunan antara lain :

1) Menahan tepi dari ukuran atau tumpukan tanah.
2) Menyokong atau menopang balok, lantai dan langit-langit.

3) Penyekat atau pembagi ruang.

4) Pelindung api dari bahaya kebakaran.

5) Latar belakang dari benda atau ruang.

6) Unsur dekorasi dalam tata ruang.

7) Menimbulkan kesan luas, tinggi atau sempit pada ruang.

Penerapan dari tema Batik Bayat dengan gaya/konsep postmodern diterapkan dengan bentuk-brntuk GRC yang dipasang pada tembok dengan motif batik brayat bagian atas dan bagian bawah menggunakan marmer warna hitam dan abu-abu.

c. Ceiling

Ceiling adalah bagian dari suatu bangunan, yang tidak lepas dari fungsi, bentuk dan karakter suatu bangunan. Pada zaman dahulu ceiling merupakan titik fokus yang kuat dari seluruh karakter suatu bangunan. Bangunan yang bersifat monumental mempunyai arti langsung terhadapkehidupan sosial budaya masyarakat saat itu. Untuk memperoleh kesan keagungan, bangunanbangunan dibuat tinggi dengan pilar-pilar besar, garis-garis vertikal lebih kuat dengan gambar-gambar dan ukiran-ukiran yang menambah keagungan bangunan. Pengertian ceiling, berasal dari kata "cell" yang berarti melindungi dengan suatu bidang antara lantai dengan atap, sehingga terbentuklah suatu ruang (Suptandar, 1999:161). Ditinjau dari fungsinya, ceiling memiliki berbagai keagungan yang jauh lebih besar dibanding dengan unsur-unsur pembentuk ruang lainnya.

Adapun bentuk dan fungsi ceiling, yaitu :

1) Sebagai pelindung kegiatan manusia sekaligus berfungsi sebagai atap.

2) Sebagai skylight yang berfungsi untuk meneruskan cahaya masuk ke dalam bangunan. Banyak digunakan pada hall suatu gedung untuk petunjuk sirkulasi 
menuju suatu tempat. Juga berfungsi untuk membuat suasana santai, memberikan perasaan lega dan lapang sebagai area transisi dari arah luar menuju ke dalam bangunan.

3) Sebagai bidang peletakan titik lampu.

4) Sebagai unsur penunjang dekorasi ruang dalam, terutama pada bangunanbangunan umum.

5) Berfungsi untuk meredam suara akustik, dengan didukung oleh dinding dan lantai.

6) Ruang yang memiliki ceiling tinggi akan terasa lebih agung, manusia akan terpaku melihat ke atas dimana titik penglihatan akan bergerak secara vertikal.

7) Perbedaan bentuk dan tinggi ceiling dapat menunjukkan perbedaan visual atas zona-zona dari ruang yang lebih luas, dan manusia dapat merasakan adanya perbedaan aktifitas dalam ruangan tersebut.

Pengkondisian ruang dalam interior meliputi :

a. Pencahayaan

Cahaya merupakan unsur yang tidak kalah penting dalam perancangan interior, karena memberi pengaruh sangat luas serta menimbulkan efek-efek tertentu. Pencahayaan ada dua jenis yaitu : pencahayaan alam (natural lighting) dan pencahayaan buatan (artificial lighting), misalnya downlight, LED, general light, dan masih banyak lagi. Pencahayaan alam (natural lighting) merupakan pencahayaan yang berasal dari sinar matahari, sinar bulan, sinar api dan sumber-sumber lain yang berasal dari alam (fosfor dan sebagainya). Pencahayaan alami dibedakan menjadi 2 macam yaitu pencahayaan langsung dan pencahayaan tidak langsung. Sedangkan pencahayaan buatan adalah pencahayaan yang berasal dari cahaya buatan manusia, misalnya lilin, sinar lampu, dan sebagainya. b. Suhu

Sumber panas terbesar yang terjadi di dalam ruangan berasal dari sinar atau cahaya matahari yang masuk ke dalam ruang melalui celah-celah dinding, jendela, lubang-lubang yang terbuka, terutama bahan yang terbuat dari kaca seperti kita lihat pada gedung-gedung saat ini (Suptandar, 1999:216). Membatasi jumlah panas yang ditimbulkan oleh cahaya yang menembus kaca, sebaiknya memakai kaca yang disebut reflection glass dengan maksud agar cahaya yang mengandung panas dapat ditinggalkan dan tidak langsung tembus ke dalam ruang atau setidaknya untuk mengurangi panas yang masuk ke dalam ruangan tersebut.

c. Akustik

Sistem akustik merupakan salah satu usaha untuk menanggulangi suara bising yang dapat mengganggu aktivitas dalam gedung pertemuan, sehingga diperoleh kualitas suara yang baik. Jenis akustik yang digunakan yaitu akustik alami (jenis akustik alami bisa menggunakan tanaman yang ada di dalam ruangan, selain sebagai bahan akustik alami, juga bisa menambah keindahan pada lobby Masjid Agung Al Aqsha tersebut) dan akustik buatan (menggunakan material penyerap bunyi pada elemen-elemen pengisi ruang, seperti gypsum board pada ceiling, panel kayu pada dinding, dan karpet pada lantai).

d. Sistem keamanan

Menambah keamanan dan kenyamanan, Perancangan Interior Masjid Agung Al-Aqsha di Klaten ini terdapat layanan security 24 jam.

Elemen pengisi ruang berfungsi untuk menunjang aktivitas di dalam ruang yang berupa furniture dan aksesoris ruang. Furniture di dalam ruang memiliki kekuatan dalam mendukung penciptaan suasana. Lebih lanjut dijelaskan bahwa gaya sebuah interior 
dapat didefinisikan dari bentuk dan gaya furniture yang ada. Penyusunan ruang harus sesuai dengan tujuan fungsi ruang tersebut, berarti penggunaan dan penyusunan perabot ditentukan oleh kebutuhan praktis dan sesuai aktivitas di dalam ruang. Untuk itu diperlukan keselarasan antara perabot-perabot pengisi ruang, ruang gerak, dan ruang pemersatu. Penggunaan perabot diusahakan multifungsi untuk efisiensi ruangan (Wilkwning, 1992:46). Elemen pengisi ruang pada Masjid agung Al Aqsha ini tentunya mengadopsi dari motifmotif batik bayat yang distilasi, sehingga gaya modern dengan sentuhan Jawa Tengah tetap terasa. Beberapa pengisi ruang yang akan didesain antara lain furniture, artwork, lampu, dan masih banyak lagi.

Proses analisis desain merupakan proses pemikiran perancangan yang didasarkan pada tuntutan ideal kondisi sosial objek garap, untuk mencari jawaban yang tepat tentang desain yang terpilih. Ada beberapa perancangan ruangan dalam proses analisisnya, yaitu : Ruang Aula, Ruang Tunggu Transit VIP, Ruang Istirahat VIP, Dapur Ruang Transit VIP, Ruang Perpustakaan dan Ruang Kantor yang berjumlah 6. Perancangan Interior Masjid Agung Al Aqsha di Klaten merupakan kegiatan menemukan ide/gagasan mengenai pembuatan Desain Interior untuk masjid yang dapat menjadikan ikon di Kabupaten Klaten dengan bangunan yang megah serta nyaman bagi jamaah yang berkunjung di masjid tersebut.

\section{PEMBAHASAN}

Masjid memiliki peranan penting bagi kehidupan sosialisasi jamaah, dengan adanya masjid maka jamaah dapat berkumpul untuk memperdalam ilmu keagamaan dengan para ahli agama yang ada di masjid tersebut dalam bentuk seminar keagamaan dll. Keberadaan Masjid Agung Al Aqsha di Klaten dengan interior yang megah namun menampilkan unsur batik bayat yang merupakan batik khas klaten, menambah daya tarik pengunjung sehingga menjadikan Masjid Agung Al Aqsha sebagai ikon dari Kabupaten Klaten. Kabupaten Klaten merupakan sebuah kabupaten di Provinsi Jawa Tengah yang berbatasan dengan Kabupaten Boyolali di bagian utara, Kabupaten Sukoharjo di bagian timur, serta Provinsi Daerah Istimewa Yogyakarta di bagian selatan dan barat. Komplek Candi Prambanan salah satu komplek candi Hindu terbesar di Indonesia berada di Kabupaten Klaten. Perancangan Interior Masjid Agung Al Aqsha di Klaten merupakan kegiatan menemukan ide/gagasan mengenai pembuatan Desain Interior untuk masjid yang dapat menjadikan ikon di Kabupaten Klaten dengan bangunan yang megah serta nyaman bagi jamaah yang berkunjung di masjid tersebut.

\subsection{Site Plan Masjid Agung Al-Aqsha di Klaten}

Masjid Aggung Al Aqsha terletak di lahan kosong dipinngir jalan raya Solo-Yogyakarta dengan luas lahan $5.266 \mathrm{~m}^{2}$. Dengan letak yang sangat strategis memudahkan para jamaah untuk menjangkaunya. Dulu merupakan terminal bus utama di Kabupaten Klaten.

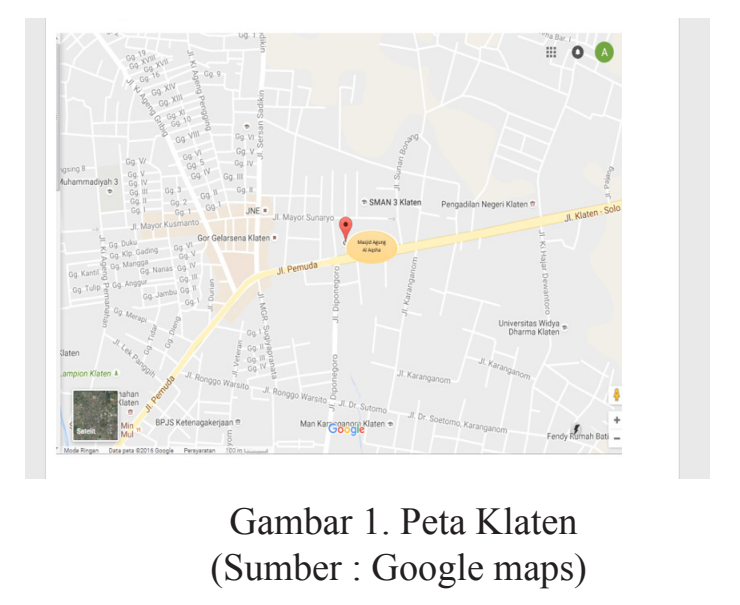




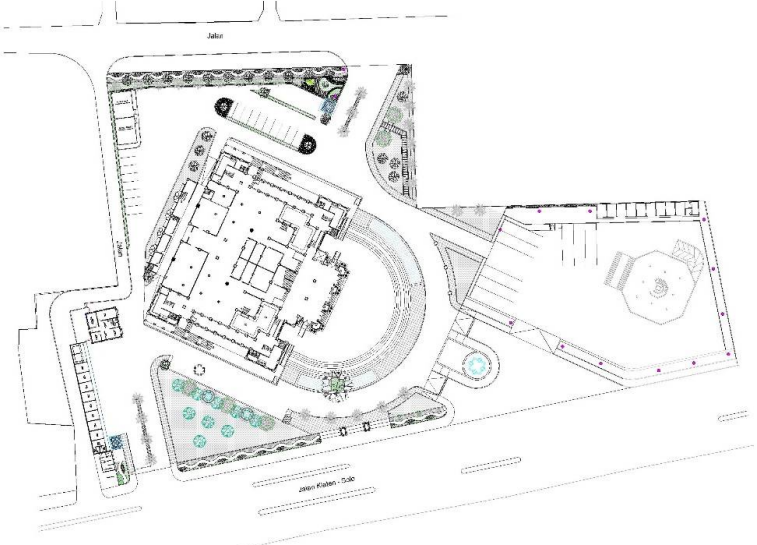

Gambar 2. Denah Eksisting Masjid Al Aqsha (Sumber : Penulis)

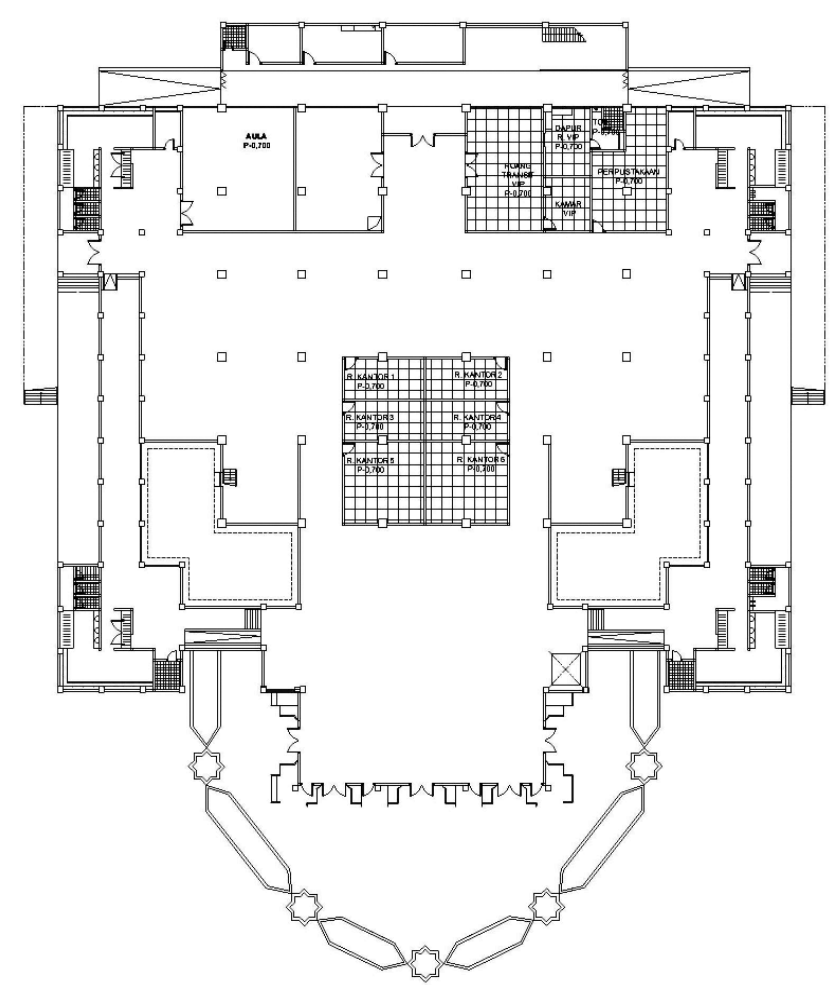

Gambar 4. Lantai Terpilih

(Sumber : Penulis)

\subsection{CEILING}

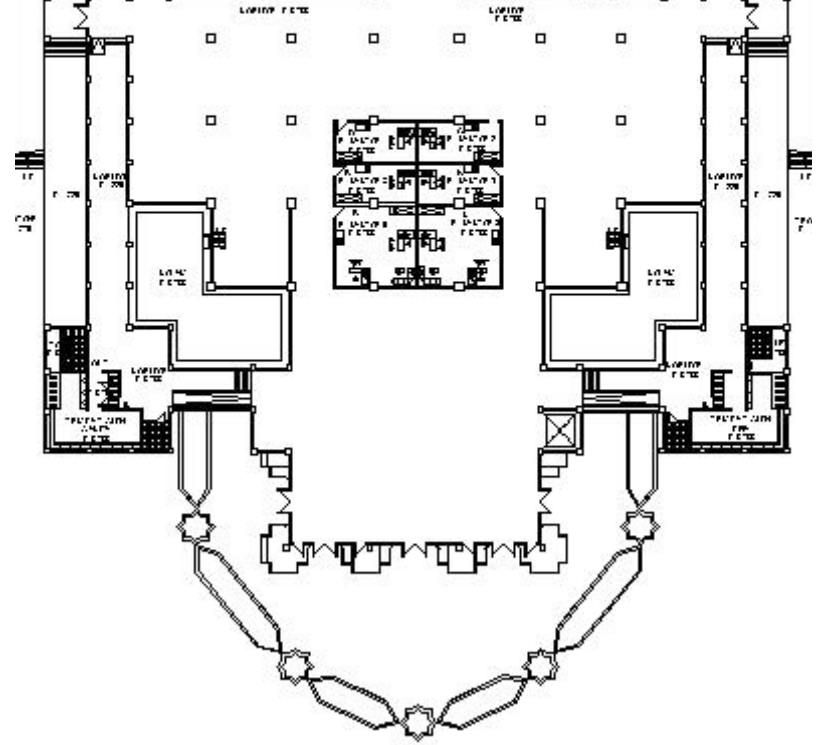

Gambar 3. Layout Terpilih (Sumber : Penulis)

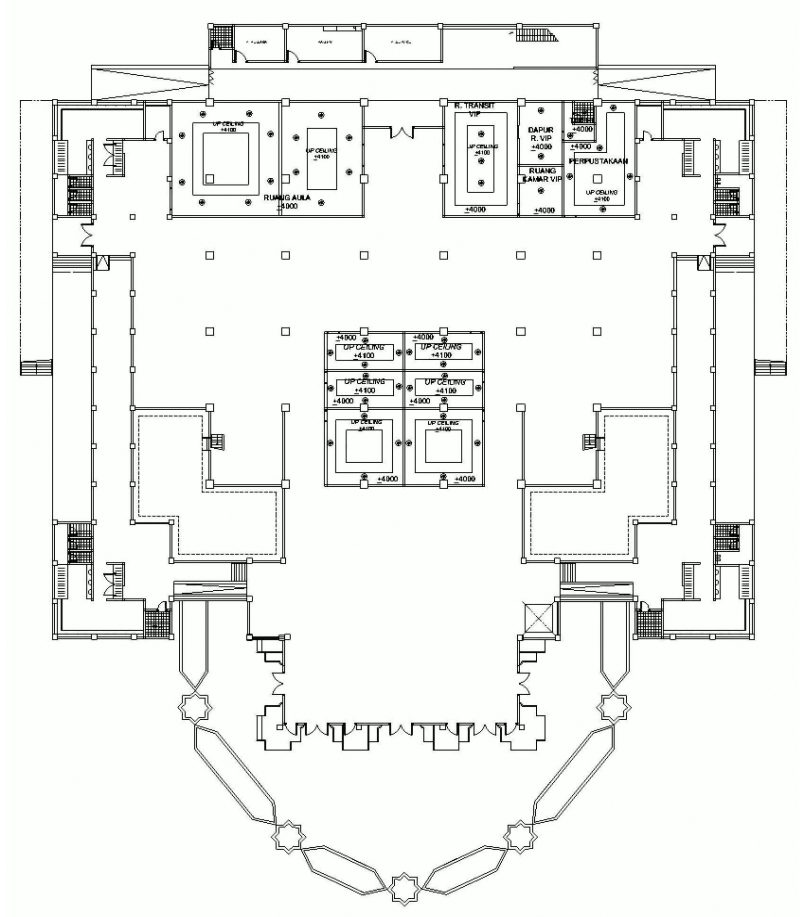

Gambar 5. Ceiling Terpilih (Sumber : Penulis)

\subsection{LANTAI}




\subsection{Unsur Pembentuk Ruang, Pengisi Ruang dan Pengkondisian Ruang}

Perancangan ini diharapkan mampu mewujudkan suatu bentuk desain yang dapat memberikan suatu wawasan dan mampu mempengaruhi emosi positif kepada para pelaku aktifitas di dalamnya. Sehingga Perancangan ini perlu adanya kelebihan dan kekurangan yang perlu diketahui, antara lain

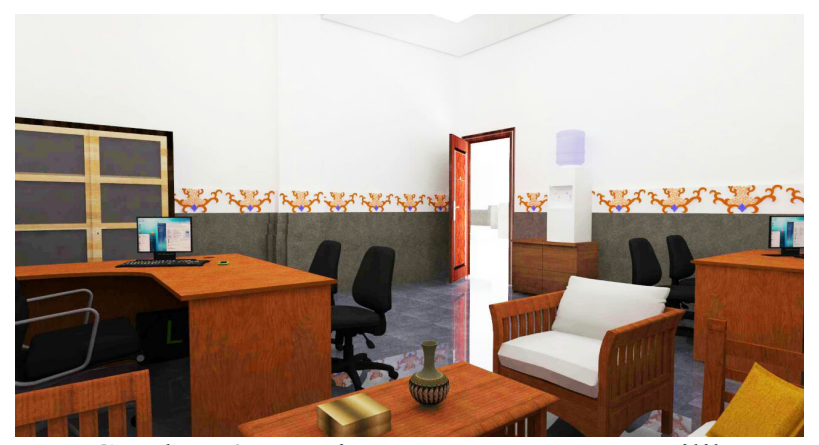

Gambar 6. Desain Ruang Kantor Terpilih (Sumber : Penulis)

Tabel 1. Analisis Desain Ruang Kantor Terpilih

\section{Kelebihan:}

a. Lantai menggunakan marmer ukuran 60x60 cm dengan warna abu-abu. Marmer dipilih untuk memberikan kesan elegan dan lebih luas. Sehingga ruang pada kantor tidak terlihat sempit dan dapat dipadukan dengan berbagai motif warna lainya karena bersifat netral.

b. Dinding menggunakan cat warna putih merk dulux. Bagian bawah dingding menggunakan marmer berwarna hitam, dan untuk batas antara dinding atas dan dinding bawah menggunakan GRC cetak dengan motif batik bayat.

c. Ceiling menggunakan gypsum dengan finising cat warna putih untuk memberikan kesan luas. Pada list menggunakan alumunium.

d. Pengisi ruang :

1. Kursi Kantor

Kursi menggunakan kursi pabrikan dengan warna hitam untum menyesuailkan dengan warna lantai.

2. Kursi Tamu

Kursi untuk tamu pada kantor menggunakan kursi kayu yang diberi bantalan berwarna putih.

3. Meja Ruang Tamu kantor

Mejaruang tamu padakantor menggunakan meja kayu.

e. Pengkondisian Ruang

1. Lampu

- General Light

- Downloght

2. Penghawaan

Menggunakan AC central untuk penghawaan.

\section{Kekurangan:}

Biaya perawatan yang cenderung mahal.

Cat tembok warna putih lebih mudah kotor dalam jangka waktu lama sehingga untuk selalu terlihat baik harus sering mengecat ulang.

Gypsum akan mudah berjamur apabila terkena air. Tetapi bias diperbaiki dengan mengecat ulang gypsum.

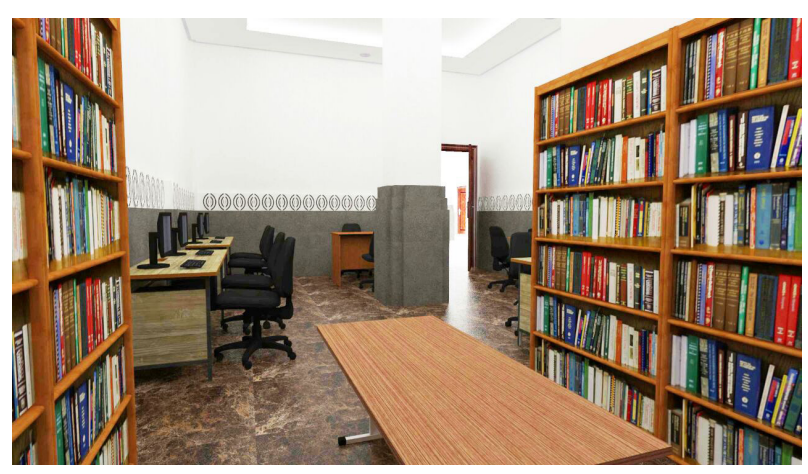

Gambar 7. Desain Ruang Perpustakaan Terpilih (Sumber : Penulis)

Tabel 2. Analisis Desain Ruang Perpustakaan Terpilih

\section{Kelebihan :}

a. Lantai menggunakan marmer tile ukuran 60x60 dengan warna coklatuntuk memberikan 
kesan elegan dan lebih luas. Sehingga ruang pada perpustakaan tidak terlihat sempit.

b. Dinding menggunakan cat warna putih merk Dulux, bagian bawah menggunakan Dtaranaki Stone warna abu-abu dengan list GRC cetak.

c. Celing menggunakan gypsum dengan finising cat warna putih untuk memberikan kesan luas. Pada list menggunakan alumunium.

d. Pengisi Ruang :

1. Kursi Komputer

Kursi menggunakan kursi pabrikan dengan warna hitam untum

\section{Kekurangan:}

1. Perawatan lantai marmer yang cenderung mahal.

2. Cat tembok lebih mudah kotor atau pudar dalam jangka waktu lama sehingga untuk selalu terlihat baik harus sering mengecat ulang.

3. Gypsum akan mudah berjamur apabila terkena air. Tetapi bisa diperbaiki dengan mengecat ulang gypsum.

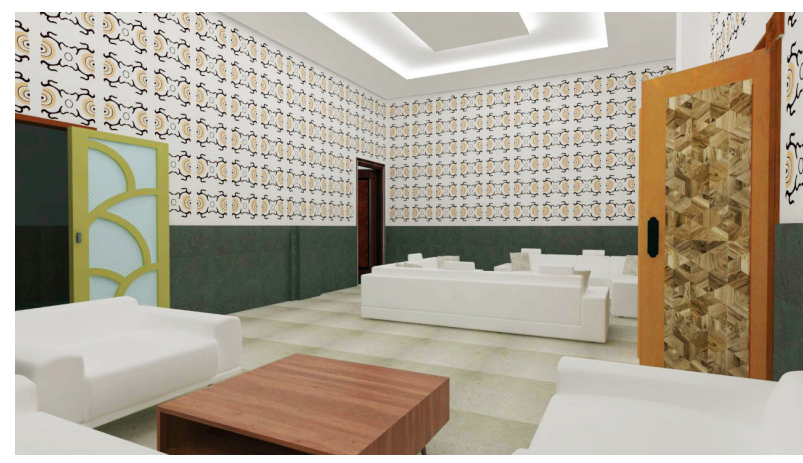

Gambar 8. Desain Ruang Transit VIP Terpilih (Sumber : Penulis)

Tabel 3. Analisis Desain Ruang Transit VIP Terpilih

\section{Kelebihan:}

a. Lantai menggunakan marmer ukuran $60 \times 60 \mathrm{~cm}$ dengan warna abu-abu.

b. Dinding menggunakan cat warna putih merk dulux. Bagian bawah dingding menggunakan marmer berwarna hitam, dan untuk batas antara dinding atas dan dinding bawah menggunakan GRC cetak dengan motif batik bayat.

c. Ceiling menggunakan gypsum dengan finising cat warna putih untuk memberikan kesan luas. Pada list menggunakan alumunium.

d. Pengisi ruang :

1. Kursi Tamu

Sofa warna putih yang berkesan elegan, bersih dan nyaman bagi mereka yang menduduki sofa tersebut.

f. Pengkondisian Ruang

1. Lampu

- General Light

- Downloght

2. Penghawaan

Menggunakan AC central untuk penghawaan.

\section{Kekurangan:}

1. Biaya perawatan yang cenderung mahal.

2. Cat tembok warna putih lebih mudah kotor dalam jangka waktu lama sehingga untuk selalu terlihat baik harus sering mengecat ulang.

3. Gypsum akan mudah berjamur apabila terkena air. Tetapi bias diperbaiki dengan mengecat ulang gypsum.

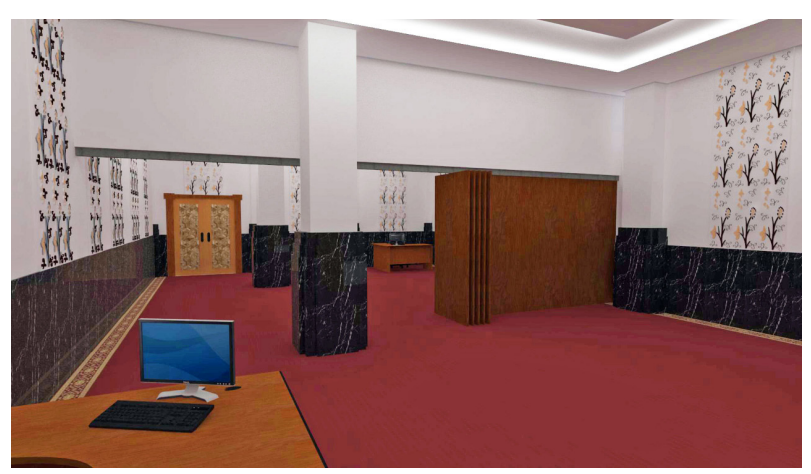

Gambar 9. Desain Ruang Aula Terpilih (Sumber : Penulis)

Tabel 4. Analisis Desain Ruang Aula Terpilih

\section{Kelebihan:}

a. Lantai menggunakan karpet warna merah dengan motif batik bagian ujung. 
b. Dinding menggunakan cat warna putih merk dulux. Bagian bawah dingding menggunakan marmer berwarna hitam, dan untuk batas antara dinding atas dan dinding bawah menggunakan GRC cetak dengan motif batik bayat.

c. Ceiling menggunakan gypsum dengan finising cat warna putih untuk memberikan kesan luas. Pada list menggunakan alumunium.

d. Pengisi ruang :

1. Kursi Komputer

Kursi menggunakan kursi pabrikan dengan warna hitam untum menyesuailkan dengan warna lantai.

2. Rolling Door

Rolling Door yang dapat diputar untuk membuat ruang aula menjadi lebar dan bisa ditutup untuk membagi ruang aula menjadi 2 bagian.

g. Pengkondisian Ruang

1. Lampu

- General Light

- Downloght

2. Penghawaan

Menggunakan AC central untuk penghawaan

\section{Kekurangan:}

1. Mudah kotor.

2. Cat tembok warna putih lebih mudah kotor dalam jangka waktu lama sehingga untuk selalu terlihat baik harus sering mengecat ulang.

3. Gypsum akan mudah berjamur apabila terkena air. Tetapi bias diperbaiki dengan mengecat ulang gypsum.

\section{SIMPULAN}

Perancangan interior Masjid Agung Al Aqsha di Klaten meliputi ruang aula, ruang transit, perpustakaan dan kantor. Masjid tersebut menggunakan gaya postmodern yang ditampilkan pada bahan yang digunakan, misal pada lantai dinding menggunakan marmer dipadukan dengan GRC cetak yang memiliki motif batik dan pada mebel menggunakan kayu tetapi lantai menggunakan marmer.

Mengusung tema muatan lokal Klabupaten Klaten yaitu batik bayat yang ditampilkan dalam unsur pembentuk ruang yaitu dinding dan karpet pada ruang aula. Perancangan tersebut dimaksudkan dapat meningkatkan daya tarik Kabupaten Klaten bagi masyarakat sekitar, dengan bangunan yang megah tapi menampilkan unsur muatan lokal batik bayat, Masjid Agung Al Aqsha menjadi ikon Kabupaten Klaten.

\section{Buku :}

\section{DAFTAR PUSTAKA}

D.K. Ching, Francis. 1996. Ilustrasi Desain Interior. Jakarta : Erlangga.

Fritz Wilkening. 1992. Tata Ruang. Semarang : Kanisius.

Laksmi. 2006. Evaluasi Ergonomi Dalam Perancangan Desain, Jurnal Desain Interior, Vol, 1, No.1

Pamudji Suptandar. 1999. Desain Interior. Jakarta : Djambatan.

Sunarmi, 2008. Buku Pegangan Kuliah Metodologi Desain. Surakarta : Program Studi Desain Interior Jurusan Seni Rupa, Institut Seni Indonesia, Surakarta. 